\title{
Toward the enrichment of HUMAN CELL
}

\author{
Isamu Ishiwata
}

Published online: 16 February 2011

(C) Japan Human Cell Society and Springer 2011

Basic and clinical research activities relating to human cells have attracted attention in recent years not only in medicine but in a diverse range of other fields as well, and interest in the subject among researchers is growing steadily.

Despite these circumstances, however, there have been few opportunities for an intensive, comprehensive presentation and discussion of research relating to human cells; thus it has not been easy to obtain the latest information. In consideration of this situation, the Human Cell Research Meeting (Nihon Hito Saibou Kenkyukai) was begun in 1983 in response to the growing number of people who expressed the need for an institution to facilitate the comprehensive presentation of research findings and exchange of opinions by people in various fields, along with the publication of a technical journal relating to human cells. The official journal of the society was first published in 1988 under the title HUMAN CELL. In 1990, the research meeting evolved into the Japan Human Cell Society, and HUMAN CELL became the official journal of the society. This publication was registered in Index Medicus and PubMed starting in 1992 and has also recently risen to the level of registration in INIS Atomindex (online edition). An editorial branch office for the publication was opened in the United States in 2004, and preparations are under way to open an editorial branch office in Europe as well.

Twenty-three volumes of HUMAN CELL have been published thus far. In recent years, cell lines derived from various human organs and tissues have become a crucial component of research on subjects such as cell metabolism, genetic analyses, physiologically active substances produced in the body, and regenerative medicine. One of the characteristics of HUMAN CELL is the large number of papers it publishes on cell line derivation. Basic research using animals is required to develop regenerative medicine into a safe and reliable treatment, and our publication accepts papers on research using animal cells. In the future, it will be necessary to rapidly disseminate outstanding research results to researchers around the world and to increase the readership of HUMAN CELL.

As the first step in achieving this goal, the publication of HUMAN CELL was commissioned to Blackwell Publishing (now Wiley-Blackwell), headquartered in Australia, starting with Volume 19. As a second, further step toward smooth publication, Springer Japan has become our publisher beginning with this issue (Volume 24). The impact factor for HUMAN CELL was 1.129 for 2009, a number that we expect to see rising. HUMAN CELL will be distributed to a large number of libraries throughout the world in the form of an electronic journal by taking advantage of Springer's international network.

We sincerely hope that many excellent manuscripts will be submitted to HUMAN CELL from countries around the world, as we declare our intention to grow as a truly international science journal in collaboration with Springer Japan.

Isamu Ishiwata

Editor-in-Chief, HUMAN CELL

I. Ishiwata $(\square)$

Ishiwata Obstetrics and Gynecology Hospital, Ibaraki, Japan

e-mail: edit-chief@humancell.jp 